Neurosurg Focus 23 (4):E2, 2007

\title{
Meningiomas: causes and risk factors
}

\author{
Jill S. Barnholtz-Sloan, Ph.D., ${ }^{1}$ and Carol Kruchko, B.A. ${ }^{2}$ \\ ${ }^{\prime}$ Case Comprehensive Cancer Center, Case Western Reserve University School of Medicine, \\ Cleveland, Ohio; ${ }^{2}$ Central Brain Tumor Registry of the United States (CBTRUS), Hinsdale, Illinois
}

\begin{abstract}
$\checkmark$ Meningiomas are among the most common primary intracranial tumors. Although the vast majority of these tumors are considered histologically benign, the incidence of complications can be high. Few studies have investigated the causes and risk factors for meningioma; this review highlights the current state of knowledge. Gaining a better understanding of the origin of this disease is essential so that treatments and outcomes can be improved and prevention strategies can be developed. (DOI: 10.3171/FOC-07/10/E2)
\end{abstract}

KEY WORDS - brain tumor • epidemiology - meningioma • risk factor

$\mathrm{M}$ ENINGIOMAS account for $30 \%$ of all primary brain tumor diagnoses in adults in the United States. ${ }^{9}$ The overall age-adjusted incidence rate is 4.52 per $100,000 .{ }^{9}$ Although age-adjusted incidence rates are reportedly similar across racial groups, the incidence in women is approximately twice that in men (Table 1). ${ }^{9}$ The incidence increases with increasing age, peaking in the seventh and eighth decades of life; these tumors are very rare in children (Fig. 1). ${ }^{9}$ It is currently estimated that $83 \%$ of all meningiomas are microscopically confirmed. ${ }^{36}$ The incidence of both diagnostically and nondiagnostically confirmed meningiomas increased between 1985 and 1999; ${ }^{36}$ on average the incidence of nondiagnostically confirmed meningiomas increased significantly at $4.1 \%$ per year $(95 \%$ CI 2.5-5.6) potentially reflecting both the increased use of improved imaging techniques such as MR imaging and increased numbers of meningiomas treated with observation or primary radiotherapy rather than through surgical intervention. A similar statistically significant difference in the average annual percent change was not seen for diagnostically confirmed meningiomas. ${ }^{36}$

The vast majority of meningiomas are considered histologically benign (92.8\%); only $2.2 \%$ are defined as uncertain or atypical, and 5\% as malignant. ${ }^{9}$ Five-year survival rates are high for this tumor type (reported to be anywhere from 70 to $95 \%)^{60,77,94}$ and therefore the estimated population prevalence (number of individuals living with this tumor) is relatively high, 50.4 per $100,000 .{ }^{15}$ Long survival times coupled with potentially significant neurocognitive and physical deficits could lead to significant medical costs over time. The estimated average years of potential life lost

Abbreviations used in this paper: $\mathrm{CI}=$ confidence interval; $\mathrm{HRT}=$ hormone replacement therapy; $\mathrm{MR}=$ magnetic resonance; $\mathrm{NF} 2$ = neurofibromatosis Type 2 ; OR = odds radio. in persons with meningiomas is 13 years, providing further evidence of the long-term burden of this disease. ${ }^{10}$

\section{Causes and Risk Factors}

In addition to increasing age, the most consistent factor associated with risk of meningioma is exposure to ionizing radiation; many other environmental, lifestyle and genetic risk factors have been studied with inconclusive results. ${ }^{12}$ Some of the factors that have been studied are endogenous and exogenous hormone use, ${ }^{11,13,33,41,49,51,97,113}$ cell phone use, ${ }^{10,28}$. $30,31,40,42,46,55,65,100$ and genetic variants or polymorphisms. ${ }^{16,17,19}$, 48,57,58,71,93,102 Other risk factors have included preexisting conditions (such as diabetes, hypertension, and epilepsy), $, 6,61$. 96,98,101 occupational lead exposure, $, 266,81,106,112$ personal hair dye use, ${ }^{5,18,80}$ radio frequency/microwave electromagnetic field exposure, ${ }^{4,23,108}$ cigarette smoking, ${ }^{38,51,61,70,75,76,78,89}$ head trau$\mathrm{ma}^{39,53,73}$ and allergies. ${ }^{6,96,99}$ For most of these factors, either no significant association or inconsistent associations with meningioma risk have been reported. Many of these studies have had small sample sizes, short follow-up times, and differences in eligibility criteria and exposure measurement, making reproducibility across studies difficult.

\section{Ionizing Radiation}

The strongest evidence to date for an increased risk of meningioma is exposure to ionizing radiation. Studies of ionizing radiation have focused on the tinea capitis cohort in Israel, ${ }^{62,84,91,92}$ atomic bomb survivors, ${ }^{79,85,90,103,104,109}$ and patients with exposures in medical and occupational settings (diagnostic or therapeutic radiation). ${ }^{43,54,69,74-76,78,83,88}$ The strongest evidence for high-dose radiation exposure in the development of meningiomas comes from individuals who underwent therapeutic radiation treatment to the head or neck for neoplastic conditions, ${ }^{1,32,35,56,63,67,69,87,105}$ whereas 


\section{J. S. Barnholtz-Sloan and C. Kruchko}

the strongest evidence for low-dose radiation exposure comes from the tinea capitis cohort studies. ${ }^{62,84,91,92}$ Studies of meningioma risk in atomic bomb survivors who received moderate to high doses of radiation - depending on their distance from the hypocenter of the bomb explosion-are less consistent, ${ }^{79,90,104}$ as is evidence from diagnostic radiation exposure from dental x-ray studies. ${ }^{54,74-76,}$ 78,83,88,95 The latency periods for meningiomas arising after radiation show a trend towards diminishing latency period with increasing radiation dose; 35.2 years for low-dose ( $<10 \mathrm{~Gy}$ ), 26.1 for moderate dose (10-20 Gy), and 19.5 years for high-dose $(>20 \mathrm{~Gy}) .^{32}$ In addition, the age at diagnosis decreases with increasing radiation dose and there is a stronger tendency toward the presence of multiple tumors with a greater likelihood of being atypical or malignant. 87,105

Between 1948 and 1960, approximately 20,000 new immigrants to Israel (mostly children) received low-dose cranial radiation for the treatment of tinea capitis, a fungal infection of the scalp. ${ }^{62,64}$ The largest cohort with long-term follow-up from this population includes approximately 11,000 patients who received radiation and an equal number of matched individuals who did not receive radiation. The patients who received radiation were individually matched by age, sex, country of birth, and year of immigration, with a sibling group that did not receive radiation..$^{91}$ Munk et al. ${ }^{64}$ were the first to report an association between irradiation for tinea capitis and meningioma; the authors of subsequent studies have shown that irradiated individuals had a 9.5-fold increased risk (95\% CI 3.5-25.7) of developing meningioma compared with individuals who did not undergo radiation ${ }^{84,91}$ over a 20 - to 30 -year period. The interplay between genetic predisposition and exposure to ionizing radiation was examined in this cohort to further refine estimates of meningioma risk. In particular, the role of genes involved in DNA repair and cell cycle pathways was examined. Sadetzki et al. ${ }^{93}$ showed that variants in the cell cycle control gene Ki-Ras and DNA repair gene $E R C C 2$ were associated with an increased risk of meningioma in the entire cohort (Ki-Ras OR [95\% CI] 1.76 [1.07-1.92]; ERCC2 OR [95\% CI] 1.68 [1.00-2.84]). Additionally they showed that there was a significant interaction between radiation status and variants in two other cell cycle control genes, cyclin D1 and p16, having an interactive, inverse effect on development of meningiomas (that is, a decreased risk) in individuals who received radiation compared with those who did not. Interestingly, in the entire cohort meningiomas developed in fewer than $1 \%$ of individuals who received radiation, supporting the idea that there are other factors (environmental, lifestyle, and/or genetic) that modify tumorigenesis after low-dose irradiation. ${ }^{21}$ A recent follow-up study in this cohort and their families supports the idea that inherited genetic susceptibility may increase the risk of developing meningioma after receiving radiation. ${ }^{21}$ Patients who had undergone radiation and subsequently developed a meningioma were more likely to have relatives affected with cancers at other irradiated sites compared with $5 \%$ of the group that did not receive radiation $(p=0.04)$. Hence, inheriting specific risk variants at key genes for tumorigenesis may make one more susceptible to the chromosome damaging effects of radiation, adversely affecting the risk of meningioma development.

Atomic bomb survivors from Hiroshima and Nagasaki
TABLE 1

Age-adjusted incidence rate of meningiomas by sex and racelethnicity*

\begin{tabular}{lcc}
\hline \hline \multicolumn{1}{c}{ Sex or Race/Ethnicity } & $\begin{array}{c}\text { Total No. } \\
\text { of Cases }\end{array}$ & $\begin{array}{c}\text { Age-Adjusted } \\
\text { Incidence Rate } \dagger\end{array}$ \\
\hline all individuals & 19,190 & 4.52 \\
w/ benign \& malignant tumors & & \\
men & 5,112 & 2.75 \\
women & 14,075 & 6.01 \\
Whites & 16,486 & 4.44 \\
Blacks & 1,762 & 4.44 \\
Hispanics of any race & 1,807 & 4.61 \\
White Hispanics & 1,656 & 4.54 \\
non-Hispanics of any race & 17,383 & 4.53 \\
White non-Hispanics & 14,830 & 4.46 \\
Black, non-Hispanics & 1,728 & 4.58 \\
w/ benign tumors only & & \\
men & 4,778 & 2.57 \\
women & 13,458 & 5.75 \\
w/ malignant tumors only & & \\
men & 334 & 0.18 \\
women & 617 & 0.26 \\
\hline
\end{tabular}

* Data based on the 1998-2002 CBTRUS report. Racial/ethnic categories are those used by the census.

$\dagger$ Incidence rates are per 100,000 person-years and are age-adjusted to the 2000 US Standard Population.

have been studied for risk of multiple different cancer types following radiation exposure from the bomb blasts.79,85, 90,103,104,109 Radiation exposure in these individuals was moderate to high depending on how close they were to the hypocenter of the blast. Seyama et al ${ }^{103}$ initially reported an increased risk of all brain tumor types in male survivors who received high-dose levels of radiation exposure, however a follow-up study in this same cohort, which included an additional 12 years of follow-up, showed no significant increase in radiation-associated brain tumor risk. ${ }^{109}$ More recently, two studies have shown an association between increased brain tumor risk (specifically meningiomas) and proximity to the hypocenter of the blast. Risk was increased in those individuals closest to the blast hypocenter who received the highest radiation doses. ${ }^{90,104}$ The most recent study of this cohort, with follow-up through 1995, showed a statistically significant dose-related increased excess risk for all brain tumors combined. ${ }^{79}$ These studies provide further evidence for an association between highdose radiation exposure and overall risk of a brain tumor, regardless of age at exposure. Further follow-up in this population is necessary to completely quantify lifetime risks for brain tumors and to fully evaluate the lifetime risk of developing specific histological tumor types.

Individuals receiving high-dose therapeutic radiation treatment to the head or neck for neoplastic conditions have also been shown to have an increased risk of developing a meningioma. ${ }^{1,32,35,56,63,67,69,87,92,105}$ Multiple studies have shown that age at high-dose therapeutic radiation treatment is directly correlated with tumor latency; the younger the age at irradiation, the shorter the latency period to meningioma formation. ${ }^{32,56,92}$ These and additional studies have shown that many of these individuals develop multiple meningiomas, that a higher proportion of these tumors tend to be atypical or malignant than would be expected and that these 


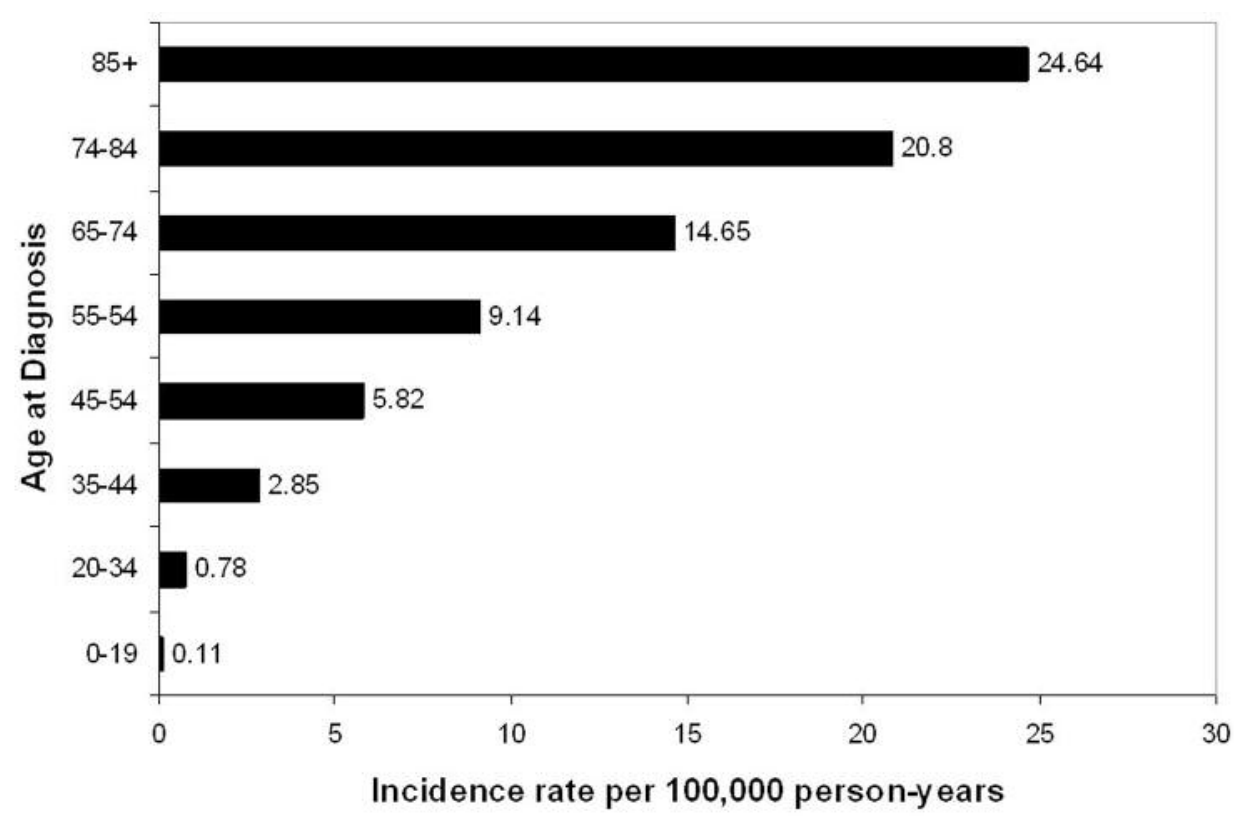

FIG. 1. Bar graph illustrating the incidence rates of meningioma (benign and malignant combined) according to patient age at diagnosis. Data based on the report of the Central Brain Tumor Registry of the United States from 1998 to 2002.

tumors have an increased recurrence rate. .,63,86,105 $^{\text {The most }}$ recent evidence for increased risk of development of meningiomas following high-dose therapeutic radiation treatment comes from studies of childhood cancer survivors. ${ }^{35,67}$ In one cohort of 14,361 5-year survivors of multiple different types of childhood cancer (The Childhood Cancer Survivor Study), radiation exposure was associated with a 9.94-fold increased risk of meningioma (95\% CI $2.17-$ 45.6), with a median latency period of 17 years and a 6.78fold increased risk of glioma (95\% CI 1.54-29.7), with a median latency period of 9 years. In another study of 2169 survivors of childhood acute lymphoblastic leukemia, meningiomas developed in $14 \%$ of individuals, with an estimated latency period of 20.6 years (95\% CI 12.6-31.7). The estimated standardized incidence ratio for development of a CNS tumor following cranial and craniospinal radiation compared to the general US population was increased by 45.8 -fold (95\% CI 26.0-64.2), while those who did not receive radiation had an increased risk of 4.3fold $(95 \%$ CI $0.1-24.0)$. Taken together these studies provide strong evidence for an increased risk for long-term development of secondary meningiomas after high-dose therapeutic radiation to the head and neck.

The primary source of diagnostic ionizing radiation to the head and neck for individuals in the United States is from diagnostic dental $\mathrm{x}$-ray studies. In particular, fullmouth series and panoramic dental radiographs use radiation beam conversion points that include parts of the meninges. Initial studies in Los Angeles, California showed that individuals who had repeated full-mouth dental x-ray exposure, particularly before the age of 20 or before 1945 , were at a four-fold increased risk of developing a meningioma ( $\mathrm{p}$ value $<0.01){ }^{74-76,78}$ However, studies conducted in populations outside the United States did not confirm these results. ${ }^{83,88,95}$ The authors of the most recent study of this exposure in the United States found that there was an increased risk of meningiomas associated with dental x-ray exposure (OR [95\% CI] 2.06 [1.03-4.17]), but only for full-mouth series that were performed at least 20 years ago when the radiation exposure was much greater than it is currently. ${ }^{54}$ Taken together, these studies imply that the radiation exposure obtained from diagnostic dental radiographs could be associated with meningioma risk, but with a long latency period of at least two decades. Other types of diagnostic x-ray studies, such as computed tomography scans, have not yet been studied on a large enough scale to form conclusive results.

\section{Hormones}

Given the predominance of meningiomas in women compared with men, the presence of hormone expression in some tumors, the possibility of an association with breast cancer, as well as reported changes in tumor size during pregnancy, the menstrual cycle, and menopause, the authors of a number of studies have focused on the relationship between hormones and meningioma risk. 11,13,33,41,49,51, 97,113

In studies of exogenous hormone exposure, researchers have looked at the risk of meningioma associated with the use of oral contraceptives and HRT in both pre- and post-

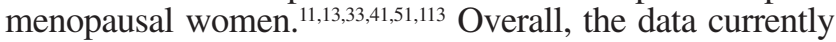
reveal no evidence for an association between oral contraceptive use and meningioma risk but do suggest a possible association with the use of HRT. ${ }^{11}$ Wigertz and colleagues ${ }^{113}$ found a significantly increased risk of meningiomas in postmenopausal women in Sweden who had ever used HRT (OR [95\% CI] 1.7 [1.0-2.8]), confirming earlier findings by Jhawar and colleagues ${ }^{41}$ within the Nurses Health Study. It should be noted that despite these reports, not all studies have supported an association between HRT use and meningiomas. ${ }^{13}$ Larger studies that examine the rela- 
tionship between exogenous hormone use and meningioma risk by hormone receptor subtype and by hormone composition (opposed compared with unopposed estrogen, for example) using a larger patient cohort are needed.

In the studies of endogenous hormone exposure, researchers have looked at the risk of meningioma associated with menopausal status, parity, ever having been pregnant, and age at menarche. ${ }^{33,41,49,51,97} \mathrm{~A}$ decreased risk of meningiomas in menopausal women has been reported ${ }^{97}$ (OR [95\% CI] $0.58[0.18-1.90])$ but was not confirmed in later studies. ${ }^{33,51}$ Lee and colleagues ${ }^{51}$ recently reported a decreased risk associated with having been pregnant at least once (OR [95\% CI] 0.4 [0.2-0.8]); an association that was stronger with increasing number of pregnancies. However this finding has not been supported by other studies of the same factor. ${ }^{41,49}$ Jhawar and associates ${ }^{41}$ demonstrated that women older than 14 at the beginning of menarche were at an increased risk (OR 95\% CI 1.97 [1.06-3.66]) of developing a meningioma compared with women in whom menarche occurred before age 12, adjusting for hormone use and menopause status. However, other studies of age at menarche show no significantly increased or decreased risk for meningioma development. ${ }^{33,51}$ In conclusion, these studies do not provide strong evidence for an association between endogenous hormone exposure and an increased risk of meningioma.

The possible relationship between breast cancer and meningiomas is scientifically intriguing. A recent study using data from the Washington State Cancer Registry ${ }^{14}$ showed that the risk of meningioma among women with breast cancer and the risk of breast cancer among women with meningioma was elevated; however, it is unclear whether the relationship is due to shared risk factors. This study involved very small numbers of women with both cancer types; this topic would benefit from study in a larger population where information is also available on other environmental, lifestyle and genetic factors.

Multiple studies have also investigated the presence of various hormone receptors (estrogen, progesterone, and/ or androgen) in meningiomas to try to explain the female predominance of this tumor. ${ }^{7,84,59,86}$ The majority of benign meningiomas express the progesterone receptor $(\sim 60$ $90 \%),{ }^{37,45,59,86}$ whereas most meningiomas do not express estrogen and androgen receptors. ${ }^{7,45,59}$ Multiple studies have shown the prognostic significance of the presence of progesterone receptors for recurrence status and recurrencefree and progression-free survival..$^{20,37,72,86,107}$ Specifically Hsu et al. ${ }^{37}$ showed in a multivariate analysis that individuals with a combination of zero nuclei staining positive for the progesterone receptor, a mitotic index greater than six, and malignant histopathological characteristics had the shortest period of progression-free survival compared to other individuals with meningiomas; hence showing that the presence of the progesterone receptor is a favorable prognostic indicator of recurrence.

How the expression of these hormone receptors in these tumors would translate into better therapeutic treatments for meningiomas remains unclear; the results from studies of antiestrogen and antiprogesterone agents have been equivocal. One study of tamoxifen (an antiestrogen therapy) as a chemotherapy for meningiomas, was too inconclusive to enable a definite recommendation about its use in this patient population. ${ }^{22}$ Authors of other studies have re- ported using an antiprogesterone (RU-486) chemotherapeutic agent to treat patients with meningiomas, but only minor radiographic tumor regression was observed in about $25 \%$ of patients. ${ }^{24,25}$

\section{Cell Phone Use}

Although public interest in the topic remains high, to date little evidence exists to suggest an association between cell phone use and the risk of meningioma. ${ }^{47}$ Multiple studies have been performed in United States, ${ }^{40,65}$ European, and Israeli populations including the Interphone case-con-

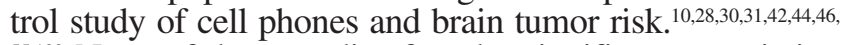
${ }^{55,100}$ None of these studies found a significant association between cell phone use and meningioma risk. However, inconsistent findings have been reported for an increased risk of acoustic neuroma, ${ }^{27-29}$ some types of high-grade gliomas ${ }^{10,29}$ and long-term cell phone usage ( $>10$ years). ${ }^{27}$, ${ }_{29,46}$ Follow-up time in the majority of these studies is relatively short and measurements of cell phone exposure vary between studies, therefore further long-term study of cell phone exposure may be warranted.

\section{Genetics}

The majority of meningiomas are sporadic tumors; patients with sporadic lesions have no family history of any kind of brain tumor. Known inherited genetic syndromes that predispose to meningioma development are few and rare. Meningioma is observed in patients with NF2, a rare autosomal dominant disorder caused by germline mutations in the NF2 gene on 22q12 (US incidence: 1 per 30,000-40,000 persons). ${ }^{3}$ However, there are probably many genes other than NF2 involved in familial meningioma. Excess familial risk of meningioma has been reported in Swedish families without any evidence of NF2 in whom there was a significant association between meningioma diagnosis and parental history of a meningioma (standardized incidence ratio [95\% CI] 3.06 [1.84-4.79]). ${ }^{34}$ In addition, in the tinea capitis cohort from Israel, the patients with meningiomas who had received radiation were more likely than those who did not to have family members affected with radiation-induced cancers, highlighting a potential inherited genetic susceptibility. Interestingly, approximately $50 \%$ of all sporadic meningiomas are also believed to harbor mutations in the NF2 gene or genetic losses that include the $22 \mathrm{q} 12$ chromosomal band. ${ }^{26,52,82}$ Additionally, sporadic meningiomas reveal a host of other chromosomal losses $(1 \mathrm{p}, 6 \mathrm{q}, 10,14 \mathrm{q}$, and $18 \mathrm{q})$ and gains $(1 \mathrm{q}, 9 \mathrm{q}, 12 \mathrm{q}, 15 \mathrm{q}, 17 \mathrm{q}$, and $20 \mathrm{q})$, many associated with tumor grade. ${ }^{50,68,111}$

A number of researchers have examined the relationship between specific genetic variants and meningioma risk, focusing on genes involved in DNA repair, cell cycle regulation, detoxification, and hormone metabolic pathways. ${ }^{16,17}$, 19,48,57,58,71,93,102 The majority of these studies have focused on variants in the GST and CYP450 genes, which are genes involved in metabolism and detoxification of exogenous and endogenous carcinogens. ${ }^{16,17,19,48,71,102}$ Results from these six studies were generally consistent, finding few significant associations with variants in these genes and an increased risk of meningioma. Authors of three of these stud- 
ies found a significantly increased risk of meningioma associated with having the GSTT1 null genotype compared to those with the GSTT1 positive genotype ( 1.5 to 3.5 fold increased risk). ${ }^{17,19,48}$ In one of these studies a significant increased risk for meningioma was found to be associated with having the GSTM3 $* B / * B$ genotype (OR [95\% CI] 3.6 [1.3-9.8]). ${ }^{16}$ The remaining two studies found no significant associations between meningioma risk and variants at various $G S T$ or $C Y P 450$ genes. $^{71,102}$

The remaining three studies focused on the most wellknown tumor suppressor gene, TP53,57,58 and on DNA repair and cell cycle control genes. ${ }^{93}$ Malmer et al. ${ }^{57}$ studied three variants in TP53 and found that overall there was no associated increased risk of meningioma for any of the individual variants or for combinations of these variants. However when restricting the analysis to individuals with a family history of cancer, the association between a specific variant combination (CC-CG-CC) and meningioma risk was a 5.69-fold increase (95\% CI 1.81-17.96) and glioma risk was a 3.62-fold increase (95\% CI 1.05-12.48). In a follow-up study, Malmer and colleagues ${ }^{58}$ again studied the same three TP53 variants and also five ATM variants, the gene responsible for regulating cellular response to DNA damage. They showed that a specific combination of variants in the ATM gene was significantly increased in patients with meningiomas $(33.8 \%)$ compared with control participants $(30.3 \%$; $\mathrm{p}$ value $=0.03)$, while a different combination was significantly decreased in patients with meningiomas $(36.1 \%)$ compared with control participants $(40.7 \%$; p-value $=0.009)$. Sadetzki et al..$^{93}$ showed that variants in Ki-RAS and ERCC2 were each associated with an approximately 2-fold increased risk of meningioma. Although these studies have yielded interesting results, a more formal large-scale, population-based study will be needed to fully assess the role of genes in the risk of meningioma development, incorporating information on various environmental and lifestyle factors.

\section{Conclusions and Future Directions}

Other than increasing age, the most consistently confirmed risk factor for meningioma is ionizing radiation exposure, despite the fact that many other environmental, lifestyle, and genetic risk factors have been studied with inconclusive results. Further studies are needed that fully integrate environmental exposure and lifestyle information with genetics, but for these studies to be scientifically meaningful they will require large sample sizes, rigorous long-term follow-up, and high-quality measurement of environmental exposure and lifestyle factors.

Recent legislation, Public Law 107-260 "The Benign Brain Tumor Cancer Registries Amendment," which went into effect January 1, 2004 now requires all state-wide cancer registries to collect incidence information on all newly diagnosed benign brain tumors in addition to the information they already collect on newly diagnosed malignant brain tumors. The Surveillance, Epidemiology, and Ends Results program of the National Cancer Institute has voluntarily agreed to collect these data. This information will provide a valuable resource not only for calculating more reliable incidence and survival rates, but also as a mechanism to identify individuals for epidemiologic and other types of research studies. In fact, the National Cancer In- stitute has recently funded the first multicenter case-control study ${ }^{12}$ to investigate environmental and genetic risk factors as well as quality of life and long-term outcomes for patients with meningiomas, utilizing cancer registry resources in five states to identify eligible individuals (http:// www.brainsciencefoundation.org and http://www.menin giomamommas.org). We hope that these and other studies will move forward the investigation of causes and risk factors for this understudied disease.

\section{Acknowledgments}

We thank Elizabeth B. Claus, M.D., Ph.D., Bridget J. McCarthy, Ph.D., and Jennifer Propp, M.S. for their insightful and helpful comments in preparing this manuscript.

\section{References}

1. Al-Mefty O, Topsakal C, Pravdenkova S, Sawyer JR, Harrison MJ: Radiation-induced meningiomas: clinical, pathological, cytokinetic, and cytogenetic characteristics. J Neurosurg 100:10021013, 2004

2. Anttila A, Heikkilä P, Nykyri E, Kauppinen T, Pukkala E, Hernberg S, et al: Risk of nervous system cancer among workers exposed to lead. J Occup Environ Med 38:131-136, 1996

3. Baser ME, R Evans DG, Gutmann DH: Neurofibromatosis 2. Curr Opin Neurol 16:27-33, 2003

4. Berg G, Spallek J, Schüz J, Schlehofer B, Böhler E, Schlaefer K, et al: Occupational exposure to radio frequency/microwave radiation and the risk of brain tumors: Interphone Study Group, Germany. Am J Epidemiol 164:538-548, 2006

5. Bluhm EC, Zahm SH, Fine HA, Black PM, Loeffler JS, Shapiro WR, et al: Personal hair dye use and risks of glioma, meningioma, and acoustic neuroma among adults. Am J Epidemiol 165: 63-71, 2007

6. Brenner AV, Linet MS, Fine HA, Shapiro WR, Selker RG, Black PM, et al: History of allergies and autoimmune diseases and risk of brain tumors in adults. Int J Cancer 99:252-259, 2002

7. Carroll RS, Zhang J, Black PM: Expression of estrogen receptors alpha and beta in human meningiomas. J Neurooncol 42: 109-116, 1999

8. Carroll RS, Zhang J, Dashner K, Sar M, Wilson EM, Black PM: Androgen receptor expression in meningiomas. J Neurosurg 82: 453-460, 1995

9. CBTRUS: Statistical Report: Primary Brain Tumors in the United States, 1998-2002. Chicago: Central Brain Tumor Registry of the United States, 2005

10. Christensen HC, Schuz J, Kosteljanetz M, Poulsen HS, Boice JD Jr, McLaughlin JK, et al: Cellular telephones and risk for brain tumors: a population-based, incident case-control study. Neurology 64:1189-1195, 2005

11. Claus EB, Black PM, Bondy ML, Calvocoressi L, Schildkraut JM, Wiemels JL, et al: Exogenous hormones use and meningioma risk: What do we tell our patients? Cancer 110:471-476, 2007

12. Claus EB, Bondy ML, Schildkraut JM, Wiemels JL, Wrensch M, Black PM: Epidemiology of intracranial meningioma. Neurosurgery 57:1088-1095, 2005

13. Custer B, Longstreth WT Jr, Phillips LE, Koepsell TD, Van Belle G: Hormonal exposures and the risk of intracranial meningioma in women: a population-based case-control study. BMC Cancer 6:152, 2006

14. Custer BS, Koepsell TD, Mueller BA: The association between breast carcinoma and meningioma in women. Cancer 94: 1626-1635, 2002

15. Davis FG, Kupelian V, Freels S, McCarthy B, Surawicz T: Prevalence estimates for primary brain tumors in the United States by behavior and major histology groups. Neuro Oncol 3: 152-158, 2001

16. De Roos AJ, Rothman N, Brown M, Bell DA, Pittman GS, 
Shapiro WR, et al: Variation in genes relevant to aromatic hydrocarbon metabolism and the risk of adult brain tumors. Neuro Oncol 8:145-155, 2006

17. De Roos AJ, Rothman N, Inskip PD, Linet MS, Shapiro WR, Selker RG, et al: Genetic polymorphisms in GSTM1, -P1, -T1, and CYP2E1 and the risk of adult brain tumors. Cancer Epidemiol Biomarkers Prev 12:14-22, 2003

18. De Roos AJ, Stewart PA, Linet MS, Heineman EF, Dosemeci M, Wilcosky T, et al: Occupation and the risk of adult glioma in the United States. Cancer Causes Control 14:139-150, 2003

19. Elexpuru-Camiruaga J, Buxton N, Kandula V, Dias PS, Campbell D, McIntosh J, et al: Susceptibility to astrocytoma and meningioma: influence of allelism at glutathione S-transferase (GSTT1 and GSTM1) and cytochrome P-450 (CYP2D6) loci. Cancer Res 55: 4237-4239, 1995

20. Fewings PE, Battersby RD, Timperley WR: Long-term follow up of progesterone receptor status in benign meningioma: a prognostic indicator of recurrence? J Neurosurg 92:401-405, 2000

21. Flint-Richter P, Sadetzki S: Genetic predisposition for the development of radiation-associated meningioma: an epidemiological study. Lancet Oncol 8:403-410, 2007

22. Goodwin JW, Crowley J, Eyre HJ, Stafford B, Jaeckle KA, Townsend JJ: A phase II evaluation of tamoxifen in unresectable or refractory meningiomas: a Southwest Oncology Group study. J Neurooncol 15:75-77, 1993

23. Grayson JK: Radiation exposure, socioeconomic status, and brain tumor risk in the US Air Force: a nested case-control study. Am J Epidemiol 143:480-486, 1996

24. Grunberg SM, Weiss MH, Russell CA, Spitz IM, Ahmadi J, Sadun A, et al: Long-term administration of mifepristone (RU486): clinical tolerance during extended treatment of meningioma. Cancer Invest 24:727-733, 2006

25. Grunberg SM, Weiss MH, Spitz IM, Ahmadi J, Sadun A, Russell $\mathrm{CA}$, et al: Treatment of unresectable meningiomas with the antiprogesterone agent mifepristone. J Neurosurg 74:861-866, 1991

26. Harada T, Irving RM, Xuereb JH, Barton DE, Hardy DG, Moffat DA, et al: Molecular genetic investigation of the neurofibromatosis type 2 tumor suppressor gene in sporadic meningioma. J Neurosurg 84:847-851, 1996

27. Hardell L, Carlberg M, Hansson Mild K: Case-control study on cellular and cordless telephones and the risk for acoustic neuroma or meningioma in patients diagnosed 2000-2003. Neuroepidemiology 25:120-128, 2005

28. Hardell L, Carlberg M, Hansson Mild K: Pooled analysis of two case-control studies on the use of cellular and cordless telephones and the risk of benign brain tumors diagnosed during 1997-2003. Int J Oncol 28:509-518, 2006

29. Hardell L, Carlberg M, Soderqvist F, Mild KK, Morgan LL: Long-term use of cellular phones and brain tumors: increased risk associated with use for $>10$ years. Occup Environ Med 120: 1769-1775, 2007

30. Hardell L, Hallquist A, Mild KH, Carlberg M, Påhlson A, Lilja A: Cellular and cordless telephones and the risk for brain tumors. Eur J Cancer Prev 11:377-386, 2002

31. Hardell L, Mild KH, Carlberg M: Case-control study on the use of cellular and cordless phones and the risk for malignant brain tumors. Int J Radiat Biol 78:931-936, 2002

32. Harrison MJ, Wolfe DE, Lau TS, Mitnick RJ, Sachdev VP: Radiation-induced meningiomas: experience at the Mount Sinai Hospital and review of the literature. J Neurosurg 75:564-574, 1991

33. Hatch EE, Linet MS, Zhang J, Fine HA, Shapiro WR, Selker RG, et al: Reproductive and hormonal factors and risk of brain tumors in adult females. Int J Cancer 114:797-805, 2005

34. Hemminki K, Li X: Familial risks in nervous system tumors. Cancer Epidemiol Biomarkers Prev 12:1137-1142, 2003

35. Hijiya N, Hudson MM, Lensing S, Zacher M, Onciu M, Behm FG, et al: Cumulative incidence of secondary neoplasms as a first event after childhood acute lymphoblastic leukemia. JAMA 297: 1207-1215, 2007

36. Hoffman S, Propp JM, McCarthy BJ: Temporal trends in incidence of primary brain tumors in the United States, 1985-1999. Neuro Oncol 8:27-37, 2006

37. Hsu DW, Efird JT, Hedley-Whyte ET: Progesterone and estrogen receptors in meningiomas: prognostic considerations. J Neurosurg 86:113-120, 1997

38. Hu J, Little J, Xu T, Zhao X, Guo L, Jia X, et al: Risk factors for meningioma in adults: a case-control study in northeast China. Int J Cancer 83:299-304, 1999

39. Inskip PD, Mellemkjaer L, Gridley G, Olsen JH: Incidence of intracranial tumors following hospitalization for head injuries (Denmark). Cancer Causes Control 9:109-116, 1998

40. Inskip PD, Tarone RE, Hatch EE, Wilcosky TC, Shapiro WR, Selker RG, et al: Cellular-telephone use and brain tumors. N Engl J Med 344:79-86, 2001

41. Jhawar BS, Fuchs CS, Colditz GA, Stampfer MJ: Sex steroid hormone exposures and risk for meningioma. J Neurosurg 99: 848-853, 2003

42. Johansen C, Boice J Jr, McLaughlin J, Olsen J: Cellular telephones and cancer-a nationwide cohort study in Denmark. J Natl Cancer Inst 93:203-207, 2001

43. Karlsson P, Holmberg E, Lundell M, Mattsson A, Holm LE, Wallgren A: Intracranial tumors after exposure to ionizing radiation during infancy: a pooled analysis of two Swedish cohorts of 28,008 infants with skin hemangioma. Radiat Res 150:357-364, 1998

44. Klaeboe L, Blaasaas KG, Tynes T: Use of mobile phones in Norway and risk of intracranial tumors. Eur J Cancer Prev 16: 158-164, 2007

45. Korhonen K, Salminen T, Raitanen J, Auvinen A, Isola J, Haapasalo H: Female predominance in meningiomas can not be explained by differences in progesterone, estrogen, or androgen receptor expression. J Neurooncol 80: 1-7, 2006

46. Lahkola A, Auvinen A, Raitanen J, Schoemaker MJ, Christensen $\mathrm{HC}$, Feychting M, et al: Mobile phone use and risk of glioma in 5 North European countries. Int J Cancer 120:1769-1775, 2007

47. Lahkola A, Tokola K, Auvinen A: Meta-analysis of mobile phone use and intracranial tumors. Scand J Work Environ Health 32: 171-177, 2006

48. Lai R, Crevier L, Thabane L: Genetic polymorphisms of glutathione S-transferases and the risk of adult brain tumors: a metaanalysis. Cancer Epidemiol Biomarkers Prev 14:1784-1790, 2005

49. Lambe M, Coogan P, Baron J: Reproductive factors and the risk of brain tumors: a population-based study in Sweden. Int J Cancer 72:389-393, 1997

50. Lamszus K, Kluwe L, Matschke J, Meissner H, Laas R, Westphal M: Allelic losses at 1p, 9q, 10q, 14q, and 22q in the progression of aggressive meningiomas and undifferentiated meningeal sarcomas. Cancer Genet Cytogenet 110:103-110, 1999

51. Lee E, Grutsch J, Persky V, Glick R, Mendes J, Davis F: Association of meningioma with reproductive factors. Int J Cancer 119: 1152-1157, 2006

52. Leone PE, Bello MJ, de Campos JM, Vaquero J, Sarasa JL, Pestaña A, et al: NF2 gene mutations and allelic status of 1p, 14q and $22 q$ in sporadic meningiomas. Oncogene 18:2231-2239, 1999

53. Longstreth WT Jr, Dennis LK, McGuire VM, Drangsholt MT, Koepsell TD: Epidemiology of intracranial meningioma. Cancer 72:639-648, 1993

54. Longstreth WT Jr, Phillips LE, Drangsholt M, Koepsell TD, Custer BS, Gehrels JA, et al: Dental X-rays and the risk of intracranial meningioma: a population-based case-control study. Cancer 100:1026-1034, 2004

55. Lönn S, Ahlbom A, Hall P, Feychting M: Long-term mobile phone use and brain tumor risk. Am J Epidemiol 161:526-535, 2005 
56. Mack EE, Wilson CB: Meningiomas induced by high-dose cranial irradiation. J Neurosurg 79:28-31, 1993

57. Malmer B, Feychting M, Lönn S, Ahlbom A, Henriksson R: p53 Genotypes and risk of glioma and meningioma. Cancer Epidemiol Biomarkers Prev 14:2220-2223, 2005

58. Malmer BS, Feychting M, Lönn S, Lindström S, Grönberg H, Ahlbom A, et al: Genetic variation in p53 and ATM haplotypes and risk of glioma and meningioma. J Neurooncol 82:229-237, 2007

59. Maxwell M, Galanopoulos T, Neville-Golden J, Antoniades HN: Expression of androgen and progesterone receptors in primary human meningiomas. J Neurosurg 78:456-462, 1993

60. McCarthy BJ, Davis FG, Freels S, Surawicz TS, Damek DM, Grutsch J, et al: Factors associated with survival in patients with meningioma. J Neurosurg 88:831-839, 1998

61. Mills PK, Preston-Martin S, Annegers JF, Beeson WL, Phillips RL, Fraser GE: Risk factors for tumors of the brain and cranial meninges in Seventh-Day Adventists. Neuroepidemiology 8: 266-275, 1989

62. Modan B, Baidatz D, Mart H, Steinitz R, Levin SG: Radiationinduced head and neck tumors. Lancet 1:277-279, 1974

63. Moss SD, Rockswold GL, Chou SN, Yock D, Berger MS: Radiation-induced meningiomas in pediatric patients. Neurosurgery 22:758-761, 1988

64. Munk J, Peyser E, Gruszkiewicz J: Radiation induced intracranial meningiomas. Clin Radiol 20:90-94, 1969

65. Muscat JE, Malkin MG, Thompson S, Shore RE, Stellman SD, McRee D, et al: Handheld cellular telephone use and risk of brain cancer. JAMA 284:3001-3007, 2000

66. Navas-Acién A, Pollán M, Gustavsson P, Plato N: Occupation, exposure to chemicals and risk of gliomas and meningiomas in Sweden. Am J Ind Med 42:214-227, 2002

67. Neglia JP, Robison LL, Stovall M, Liu Y, Packer RJ, Hammond $\mathrm{S}$, et al: New primary neoplasms of the central nervous system in survivors of childhood cancer: a report from the Childhood Cancer Survivor Study. J Natl Cancer Inst 98:1528-1537, 2006

68. Ozaki S, Nishizaki T, Ito H, Sasaki K: Comparative genomic hybridization analysis of genetic alterations associated with malignant progression of meningioma. J Neurooncol 41:167-174, 1999

69. Phillips LE, Frankenfeld CL, Drangsholt M, Koepsell TD, van Belle G, Longstreth WT Jr: Intracranial meningioma and ionizing radiation in medical and occupational settings. Neurology 64: 350-352, 2005

70. Phillips LE, Longstreth WT Jr, Koepsell T, Custer BS, Kukull WA, van Belle G: Active and passive cigarette smoking and risk of intracranial meningioma. Neuroepidemiology 24:117-122, 2005

71. Pinarbasi H, Silig Y, Gurelik M: Genetic polymorphisms of GSTs and their association with primary brain tumor incidence. Cancer Genet Cytogenet 156:144-149, 2005

72. Pravdenkova S, Al-Mefty O, Sawyer J, Husain M: Progesterone and estrogen receptors: opposing prognostic indicators in meningiomas. J Neurosurg 105:163-173, 2006

73. Preston-Martin S: Descriptive epidemiology of primary tumors of the brain, cranial nerves and cranial meninges in Los Angeles County. Neuroepidemiology 8:283-295, 1989

74. Preston-Martin S, Henderson BE, Bernstein L: Medical and dental $\mathrm{x}$ rays as risk factors for recently diagnosed tumors of the head. Natl Cancer Inst Monogr 69:175-179, 1985

75. Preston-Martin S, Mack W, Henderson BE: Risk factors for gliomas and meningiomas in males in Los Angeles County. Cancer Res 49:6137-6143, 1989

76. Preston-Martin S, Paganini-Hill A, Henderson BE, Pike MC, Wood C: Case-control study of intracranial meningiomas in women in Los Angeles County, California. J Natl Cancer Inst 65: 67-73, 1980

77. Preston-Martin S, Staples M, Farrugia H, Giles G: Primary tumors of the brain, cranial nerves and cranial meninges in Victoria,
Australia, 1982-1990: patterns of incidence and survival. Neuroepidemiology 12:270-279, 1993

78. Preston-Martin S, Yu MC, Henderson BE, Roberts C: Risk factors for meningiomas in men in Los Angeles County. J Natl Cancer Inst 70:863-866, 1983

79. Preston DL, Ron E, Yonehara S, Kobuke T, Fujii H, Kishikawa $\mathrm{M}$, et al: Tumors of the nervous system and pituitary gland associated with atomic bomb radiation exposure. J Natl Cancer Inst 94:1555-1563, 2002

80. Rajaraman P, De Roos AJ, Stewart PA, Linet MS, Fine HA, Shapiro WR, et al: Occupation and risk of meningioma and acoustic neuroma in the United States. Am J Ind Med 45: 395-407, 2004

81. Rajaraman P, Stewart PA, Samet JM, Schwartz BS, Linet MS, Zahm SH, et al: Lead, genetic susceptibility, and risk of adult brain tumors. Cancer Epidemiol Biomarkers Prev 15:2514 2520, 2006

82. Riemenschneider MJ, Perry A, Reifenberger G: Histological classification and molecular genetics of meningiomas. Lancet Neurol 5:1045-1054, 2006

83. Rodvall Y, Ahlbom A, Pershagen G, Nylander M, Spännare B: Dental radiography after age 25 years, amalgam fillings and tumors of the central nervous system. Oral Oncol 34:265-269, 1998

84. Ron E, Modan B, Boice JD Jr, Alfandary E, Stovall M, Chetrit A, et al: Tumors of the brain and nervous system after radiotherapy in childhood. N Engl J Med 319:1033-1039, 1988

85. Ron E, Preston DL, Mabuchi K, Thompson DE, Soda M: Cancer incidence in atomic bomb survivors. Part IV: Comparison of cancer incidence and mortality. Radiat Res 137 (Suppl 2):S98S112, 1994

86. Roser F, Nakamura M, Bellinzona M, Rosahl SK, Ostertag H, Samii M: The prognostic value of progesterone receptor status in meningiomas. J Clin Pathol 57:1033-1037, 2004

87. Rubinstein AB, Shalit MN, Cohen ML, Zandbank U, Reichenthal E: Radiation-induced cerebral meningioma: a recognizable entity. J Neurosurg 61:966-971, 1984

88. Ryan P, Lee MW, North B, McMichael AJ: Amalgam fillings, diagnostic dental $\mathrm{X}$-rays and tumors of the brain and meninges. Eur J Cancer B Oral Oncol 28B:91-95, 1992

89. Ryan P, Lee MW, North B, McMichael AJ: Risk factors for tumors of the brain and meninges: results from the Adelaide Adult Brain Tumor Study. Int J Cancer 51:20-27, 1992

90. Sadamori N, Shibata S, Mine M, Miyazaki H, Miyake H, Kurihara $\mathrm{M}$, et al: Incidence of intracranial meningiomas in Nagasaki atomic-bomb survivors. Int J Cancer 67:318-322, 1996

91. Sadetzki S, Chetrit A, Freedman L, Stovall M, Modan B, Novikov I: Long-term follow-up for brain tumor development after childhood exposure to ionizing radiation for tinea capitis. Radiat Res 163:424-432, 2005

92. Sadetzki S, Flint-Richter P, Ben-Tal T, Nass D: Radiation-induced meningioma: a descriptive study of 253 cases. J Neurosurg 97: 1078-1082, 2002

93. Sadetzki S, Flint-Richter P, Starinsky S, Novikov I, Lerman Y, Goldman B, et al: Genotyping of patients with sporadic and radiation-associated meningiomas. Cancer Epidemiol Biomarkers Prev 14:969-976, 2005

94. Sankila R, Kallio M, Jaaskelainen J, Hakulinen T: Long-term survival of 1986 patients with intracranial meningioma diagnosed from 1953 to 1984 in Finland. Comparison of the observed and expected survival rates in a population-based series. Cancer 70: 1568-1576, 1992

95. Schlehofer B, Blettner M, Becker N, Martinsohn C, Wahrendorf J: Medical risk factors and the development of brain tumors. Cancer 69:2541-2547, 1992

96. Schlehofer B, Blettner M, Preston-Martin S, Niehoff D, Wahrendorf J, Arslan A, et al: Role of medical history in brain tumor development. Results from the international adult brain tumor study. Int J Cancer 82:155-160, 1999 


\section{J. S. Barnholtz-Sloan and C. Kruchko}

97. Schlehofer B, Blettner M, Wahrendorf J: Association between brain tumors and menopausal status. J Natl Cancer Inst 84: 1346-1349, 1992

98. Schneider B, Pülhorn H, Röhrig B, Rainov NG: Predisposing conditions and risk factors for development of symptomatic meningioma in adults. Cancer Detect Prev 29:440-447, 2005

99. Schoemaker MJ, Swerdlow AJ, Hepworth SJ, McKinney PA, van Tongeren M, Muir KR: History of allergies and risk of glioma in adults. Int J Cancer 119:2165-2172, 2006

100. Schüz J, Böhler E, Berg G, Schlehofer B, Hettinger I, Schlaefer K, et al: Cellular phones, cordless phones, and the risks of glioma and meningioma (Interphone Study Group, Germany). Am J Epidemiol 163:512-520, 2006

101. Schwartzbaum J, Jonsson F, Ahlbom A, Preston-Martin S, Malmer B, Lönn S, et al: Prior hospitalization for epilepsy, diabetes, and stroke and subsequent glioma and meningioma risk. Cancer Epidemiol Biomarkers Prev 14:643-650, 2005

102. Schwartzbaum JA, Ahlbom A, Lönn S, Warholm M, Rannug A, Auvinen A, et al: An international case-control study of glutathione transferase and functionally related polymorphisms and risk of primary adult brain tumors. Cancer Epidemiol Biomarkers Prev 16:559-565, 2007

103. Seyama S, Ishimaru T, Ijima S, Mori K: Primary intracranial tumors among atomic bomb survivors and controls, Hiroshima and Nagasaki, 1961-1975. J Hiroshima Med Assoc 34: 1056-1065, 1981

104. Shintani T, Hayakawa N, Hoshi M, Sumida M, Kurisu K, Oki $\mathrm{S}$, et al: High incidence of meningioma among Hiroshima atomic bomb survivors. J Radiat Res 40:49-57, 1999

105. Soffer D, Pittaluga S, Feiner M, Beller AJ: Intracranial meningiomas following low-dose irradiation to the head. J Neurosurg 59:1048-1053, 1983

106. Steenland K, Boffetta P: Lead and cancer in humans: where are we now? Am J Ind Med 38:295-299, 2000

107. Strik HM, Strobelt I, Pietsch-Breitfeld B, Iglesias-Rozas JR, Will B, Meyermann R: The impact of progesterone receptor expression on relapse in the long-term clinical course of 93 benign meningiomas. In Vivo 16:265-270, 2002
108. Thomas TL, Stolley PD, Stemhagen A, Fontham ET, Bleecker ML, Stewart PA, et al: Brain tumor mortality risk among men with electrical and electronics jobs: a case-control study. J Natl Cancer Inst 79:233-238, 1987

109. Thompson DE, Mabuchi K, Ron E, Soda M, Tokunaga M, Ochikubo S, et al: Cancer incidence in atomic bomb survivors. Part II: Solid tumors, 1958-1987. Radiat Res 137 (Suppl 2): S17-S67, 1994

110. Thuppal S, Propp JM, McCarthy BJ: Average years of potential life lost in those who have died from brain and CNS tumors in the USA. Neuroepidemiology 27:22-27, 2006

111. Weber RG, Bostrom J, Wolter M, Baudis M, Collins VP, Reifenberger $\mathrm{G}$, et al: Analysis of genomic alterations in benign, atypical, and anaplastic meningiomas: toward a genetic model of meningioma progression. Proc Natl Acad Sci U S A 94: 14719-14724, 1997

112. Wesseling C, Pukkala E, Neuvonen K, Kauppinen T, Boffetta P, Partanen T: Cancer of the brain and nervous system and occupational exposures in Finnish women. J Occup Environ Med 44:663-668, 2002

113. Wigertz A, Lönn S, Mathiesen T, Ahlbom A, Hall P, Feychting M: Risk of brain tumors associated with exposure to exogenous female sex hormones. Am J Epidemiol 164:629-636, 2006

Manuscript submitted July 10, 2007.

Accepted August 7, 2007.

Funding for the Central Brain Tumor Registry of the United States by contract number 2004-01218 from the Centers for Disease Control and Prevention.

Address correspondence to: Jill S. Barnholtz-Sloan, Ph.D., Case Comprehensive Cancer Center, Case Western Reserve University School of Medicine, 11100 Euclid Avenue, Wearn 15, Cleveland, Ohio 44106-5065. email: jsb42@ case.edu. 